\title{
Can serum markers of brain injury predict neurological outcome after out-of-hospital cardiac arrest? Author's reply
}

\author{
Marion Moseby-Knappe ${ }^{*}$ (i) and Tobias Cronberg
}

(c) 2021 Springer-Verlag GmbH Germany, part of Springer Nature

We are grateful for the interest in our study shown by $\mathrm{Li}$ and Wang who raise concerns about the methods used and interpretation of results [1].

We investigated whether levels of brain injury markers could be used to predict good neurological outcome according to the Cerebral Performance Category Scale $(\mathrm{CPC})$ at 6 months after cardiac arrest [2]. Li and Wang question the necessity of predictors of a good outcome since the majority of cardiac arrest survivors from the TTM-trial belonged to this category [3]. Nonetheless, the majority of cardiac arrest trials permit withdrawal of lifesustaining therapy in patients with a futile prognosis, and patients may be of risk for self-fulfilling prophecies [4].

We found that normal levels of brain injury markers correctly identified unconscious patients with little or no brain injury [2]. In our opinion, these results can be implemented directly within clinical practice, since it helps avoid terminating treatment in patients with a presumed good neurological outcome. We acknowledge that our results are indeed limited by the lack of standardization within analysis of brain injury markers and further research should be encouraged. Nonetheless, falsely elevated levels of brain injury markers for any reason should not be a major issue when predicting a favorable outcome.

$\mathrm{Li}$ and Wang also raise concerns with the low incidence of generalized edema on computed tomography in Table 4 of our article. This is understandable, yet this table only includes neuroprognostic findings in patients with normal levels of brain injury markers (i.e. presumed favorable outcome). The low number of pathological findings in these patients is a strong indicator of the validity

${ }^{*}$ Correspondence: marion.moseby_knappe@med.lu.se

Department of Clinical Sciences Lund, Neurology, Lunds University, Lund, Sweden of the predictive value of brain injury markers. We consider the discrepancies between single false pathological findings and normal biomarkers to be very useful to avoid false pessimistic predictions of poor outcome.

\section{Declarations}

Conflicts of interest

MMK and TC have no conflicts of interest.

\section{Publisher's Note}

Springer Nature remains neutral with regard to jurisdictional claims in published maps and institutional affiliations.

Accepted: 1 December 2021

Published online: 16 December 2021

\section{References}

1. LiW, Wang J (2021) Can serum brain injury markers predict neurological outcome after out-of-hospital cardiac arrest. Intensive Care Med. https:// doi.org/10.1007/s00134-021-06594-w

2. Moseby-Knappe M, Mattsson-Carlgren N, Stammet P, Backman S, Blennow K, Dankiewicz J, Friberg H, Hassager C, Horn J, Kjaergaard J, Lilja G, Rylander C, Ullen S, Unden J, Westhall E, Wise MP, Zetterberg H, Nielsen N, Cronberg T (2021) Serum markers of brain injury can predict good neurological outcome after out-of-hospital cardiac arrest. Intensive Care Med 47(9):984-994. https://doi.org/10.1007/s00134-021-06481-4

3. Nielsen N, Wetterslev J, Cronberg T, Erlinge D, Gasche Y, Hassager C, Horn J, Hovdenes J, Kjaergaard J, Kuiper M, Pellis T, Stammet P, Wanscher M, Wise MP, Aneman A, Al-Subaie N, Boesgaard S, Bro-Jeppesen J, Brunetti I, Bugge JF, Hingston CD, Juffermans NP, Koopmans M, Kober L, Langorgen J, Lilja G, Moller JE, Rundgren M, Rylander C, Smid O, Werer C, Winkel P, Friberg H, Investigators TTMT (2013) Targeted temperature management at $33^{\circ} \mathrm{C}$ versus $36^{\circ} \mathrm{C}$ after cardiac arrest. N Engl J Med 369(23):2197-2206. https://doi.org/10.1056/NEJMoa1310519

4. Sandroni C, D'Arrigo S, Cacciola S, Hoedemaekers CWE, Kamps MJA, Oddo M, Taccone FS, Di Rocco A, Meijer FJA, Westhall E, Antonelli M, Soar J, Nolan JP, Cronberg T (2020) Prediction of poor neurological outcome in comatose survivors of cardiac arrest: a systematic review. Intensive Care Med. https://doi.org/10.1007/s00134-020-06198-w 